\title{
DO QUASI-USUFRUCTO NO DIREITO ACTUAL
}

Sendo o usufructo um "jus alienis rebus utendi, fruendi, salva rerum substantia", é evidente que não pode recahir sobre cousas consumiveis pelo proprio uso normal. Esta orientação prevaleceu no Direito Romano até o comeŗo do Imperio. Razões de utilidade, porem, determinaram a derogação do principio. A lei Julia Papia Pappea do tempo de Octavio restringira as liberalidades mortis causa entre conjuges, ao simples usufructo de uma quota parte dos bens do outro conjuge pré morto. Uma successão, em regra, comprehende cousas de que se não podem usar, sem consumir. Neste caso a severa applicação do principio produsiria o effeito de privar o conjuge sobrevivente das vantagens que a referidla Lei parecila conceder-lhe e tornaria inefficaz a disposição testamentaria, contra o espirito do Direito Romano. Certamente foram estas considerações que determinaram o Senatus Consultus, do tẹmpo de Tíberio, que concedeu a faculdade de legar um patrimonio composto ide cousas de qualquer natureza, e providenciou sobre o modo de executar este preceito. Estabelecido o principio para as liberalidades mortis causa, foi logo ampliado nos actos inter vivas, applicando-se mesmo ás cousas incorporeas el, particularmente aos capitaes. Creou-se, assim, como diz Gayus, não um usufructo sobre estas cousas, mas um-quasi usufructo, assegurado por uma caução prestada pelo quasi usufructuario. O usufructuario de cousas consumiveis pelo proprio uso adquire - para logo - a propriedade dellas, ficando, porem, obrigado, findo o usufructo, a restituir o 
equivalente, em genero, qualidade e quantidade, ou não sendo possivel, o seu valor, pelo preço corrente no tempo da restituição - Cod. Civ, art. 726. Si, porem, as cousas forem avaliadas no titulo de constituição do direito, salvo clausula em contrario, serão pagas pelo preço da avaliação. Cod. Civ. cit. art. $726 \oint$ unico.

Em ambos os casos a restituição em especie ou em moeda é garantida pela caução estatuida no C. C. art. 729.

E' evidiente que o anterior proprietario não conserva nenhum direito rẹal sobre as cousas que - para logo - passam para o dominio do usufructuario C. C. art. 726. Elle tem somente um direito obrigacional sobre o valor das mesmas cousas, no fim do contracto. De accordo com o systema do C. C. art. 726 o quasi usufructo ou usufructo sobre cousas que se consomem pelo uso, é o mesmo emprestimo para consumo, ou o mutuo com caução e, no caso do paragrapho unico do cit. art. 726 , reveste a figura juridica da venda a termo, sendo-lhe, portanto, applicaveis as disposiçõed que regem estes institutos.

$A^{\prime}$ vista do exposto é forçoso concluir: - que o art. 726 dlo Cod. Civ. está mal collocado e que o quasi usufructo é incompativel com a noção fundamental e natureza do usufructo. Actualmente é, na expressãd incisina de Cochafel. — “uma incongruencia juridica e um contrasenso legal"

S. Paulo dezembro de 1926.

M. Pacheco Prates. 